\title{
Effects of Incorporating Banana Skin Powder (BSP) and Palm Oil Fuel Ash (POFA) on Mechanical Properties of Lightweight Foamed Concrete
}

\section{N. Mohamad ${ }^{1}$, A. A. A. Samad ${ }^{1, *}$, Muhammad Tahir Lakhiar ${ }^{1}$, Md Azree Othuman Mydin', Suriani Jusoh ${ }^{3}$, A. Sofia ${ }^{4}$, Suaidi Azis Efendi ${ }^{1}$}

\author{
${ }^{1}$ Faculty of Civil and Environment Engineering \\ Universiti Tun Hussein Onn Malaysia, 86400, Parit Raja, Batu Pahat, Johor, MALAYSIA \\ ${ }^{2}$ School of Housing, Building and Planning \\ Universiti Sains Malaysia, 11800, Penang, MALAYSIA \\ ${ }^{3}$ School of Ocean Engineering \\ Universiti Malaysia Terengganu, 21300 Kuala Nerus, Terengganu, MALAYSIA \\ ${ }^{4}$ School of Materials \\ Universiti Malaysia Perlis, 02600 Arau, Perlis, MALAYSIA
}

Received 12 August 2018; accepted 11 December 2018, available online 31 December 2018

\begin{abstract}
This paper presents the effects of agricultural wastes on the mechanical properties of lightweight foamed concrete, LFC. The agricultural wastes utilized in this research are banana skin powder (BSP) and palm oil fuel ash (POFA) as cement and sand replacement, respectively. Physical and chemical tests were conducted to determine the chemical composition and particle size of both BSP and POFA. These chemical and physical properties of the raw materials are important in understanding the effects they have on the mechanical properties of lightweight foamed concrete incorporating BSP and POFA, which is designated as LFC-BSP-POFA. Cube, cylindrical, and prism specimens of LFC-BSP-POFA with density of $1800 \mathrm{~kg} / \mathrm{m}^{3}$ were cast and tested to determine its compressive strength, tensile strength, modulus of elasticity and flexural strength. Twelve (12) LFC-BSPPOFA mixtures were prepared with content of BSP as cement replacement of $0 \%, 0.2 \%, 0.4 \%, 0.6 \%, 0.8 \%$ and $1 \%$ by weight. For each mixture, the content of POFA as sand replacement are $0 \%$ and $15 \%$. It was found that BSP and POFA each contain $55.98 \%$ and $51.83 \%$ silicon dioxide, and $2.71 \%$ and $2.32 \%$ aluminum oxide, respectively. The particle size for these two materials as obtained from PSA test showed that both materials are considered as fine particles, which is within $0.1 \mu \mathrm{m}$ to $250 \mu \mathrm{m}$. These chemical composition and particle size of BSP and POFA contribute to the pozzolanic reaction in LFC. This is proven by the results obtained from the mechanical properties tests which show that the incorporation of both BSP and POFA as cement and sand replacement have some significant effects on the mechanical properties of LFC. The increase percentage of BSP and POFA incorporated in LFC had shown slight increment in its mechanical properties.
\end{abstract}

Keywords: Agricultural waste, lightweight foamed concrete, chemical and physical properties, mechanical properties

\section{Introduction}

Foam concrete is a type of lightweight concrete which is produced from mixture of cement, sand and water with added foam. Foam produces pores in the concrete which reduce its self-weight. This concrete is called lightweight foamed concrete, LFC. LFC has the density ranging from $300 \mathrm{~kg} / \mathrm{m}^{3}$ to $1840 \mathrm{~kg} / \mathrm{m}^{3}$ [1]. For normal concrete, the density is in the range of $2240 \mathrm{~kg} / \mathrm{m}^{3}$ to $2400 \mathrm{~kg} / \mathrm{m}^{3}$ which is around $87 \%$ to $23 \%$ of unit weight compared to lightweight concrete [2]. There are many applications of lightweight concrete in building construction which include as partition, slab, and wall panel [3]. Recently, the technology of LFC is enhancing even more with the addition of waste material, either as cement or sand replacement or as filler in the foam concrete mixture. Studies was conducted on durability performance of LFC strengthened with coir fiber[4, 5] It was found in both studies that coconut fiber added as filler in FC resulted with enhanced compression and tensile strength. There has been no study of BSP incorporated in LFC, but there were studies conducted on BSP in fly ash concrete [6], and as admixture in conventional concrete mixture[7]. 
Partial replacement of cement with fly ash improved the resistance of banana fibre reinforced concrete to sulphate attack with the specimens containing $20 \%$ replacement of cement. Meanwhile, using dried banana peel powder as admixture in conventional concrete increased its flexural strength but with considerable lesser compressive strength.

Meanwhile, agricultural wastes have contributed to the abundance of wastes left unmanaged in the open field. Agricultural waste is stated as a waste formed as a product or by-product from different agricultural activities. These wastes contribute to over $30 \%$ of worldwide agricultural productivity. The agricultural and food industry wastes form a remarkable proportion of worldwide agricultural productivity [8]. These wastes, if not managed properly, could lead to serious environmental issues. One of the methods to control this abundance of wastes is by recycling them as the construction material. It has been studied that certain agricultural wastes incorporated in the concrete mixture has potential to enhance the concrete's fresh and hardened properties.

Banana skin fibers has found to increase the tensile strength and tensile modulus of composites at optimum usage of 5\% [9]. A research was conducted on the mechanical and thermal characterization of banana peel fibers/HDPE composites where the banana fibers were mixed with high density polyethylene to produce the banana peel fibers/HDPE composites. This composite was characterized by tensile test and thermal analysis. It is found that $5 \%$ of fibers improved the tensile strength of composite in comparison with the pure HDPE. It is also found that the addition of fibers decreased the thermal stability of composites but increased its thermal crystallization temperature [10]. Replacement of $40 \%$ fly ash in the self-compacting concrete mixture had resulted with optimum workability, compressive strength and modulus of elasticity of the mixture with the highest compressive strength achieved was 27.2 MPa and MOE $31 \mathrm{GPa}$ [11]. Meanwhile the optimum percentage of POFA in SCC mixture was found to be $5 \%$ where highest compressive strength was achieved, which is $38.4 \mathrm{MPa}$ and modulus of elasticity of 31.6 GPa [12]. POFA, a byproduct obtained by burning of fibers, shells and empty fruit bunches as fuel in palm oil mills, contains pozzolanic properties is also considered as a promising supplementary cementing material. The incorporation of pozzolans, either naturally occurring or artificially made into concrete has been in practice since early civilization [13]. A review on potential mixture of POFA as cement replacement was conducted, where it is proven that by incorporating POFA in a concrete mixture, enhanced mechanical properties would occur, provided the optimum volume of POFA was utilized [14]. In a study conducted on fresh state and mechanical properties of self-compacting concrete with added POFA, the results obtained indicated that replacement of 5\% POFA is the optimum value for cement replacement to obtain high workability and mechanical properties of concrete [15].
The use of pozzolanic materials as partial cement replacement in concrete mixtures is vital due to environmental concerns such as $\mathrm{CO}_{2}$ emission to the atmosphere. This paper reported the chemical compositions and particle size of BSP and POFA. It also presents the effects of these two agricultural wastes as cement and sand replacement on LFC-BSP-POFA's mechanical properties.

\section{Materials and method}

The materials involved in this study are ordinary Portland cement, sand, water and foam to cast the lightweight foamed concrete, BSP and POFA. The OPC used throughout this research is complied with BS EN197:Part 1:2000 [16] and sieved under $150 \mu \mathrm{m}$ sieve. For this research, the banana skin were produced into a powder form where the banana skin were dried in the oven at temperature $105^{\circ} \mathrm{C} \pm 5^{\circ} \mathrm{C}$ for 24 hours. The dried banana skins were then grinded and sieved under $150 \mu \mathrm{m}$ sieve. POFA was obtained from Ban Dung Palm Oil Industries Sdn. Bhd. at Parit Sulong, Batu Pahat, Johor. Fig. 1 and Fig. 2 show the BSP and POFA, both in powder form.

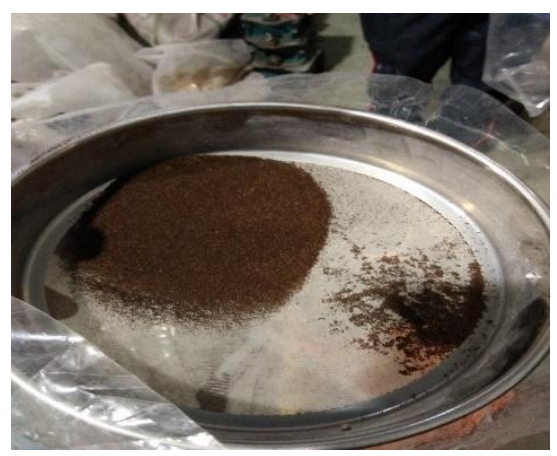

Fig.1 Banana skin powder (BSP)

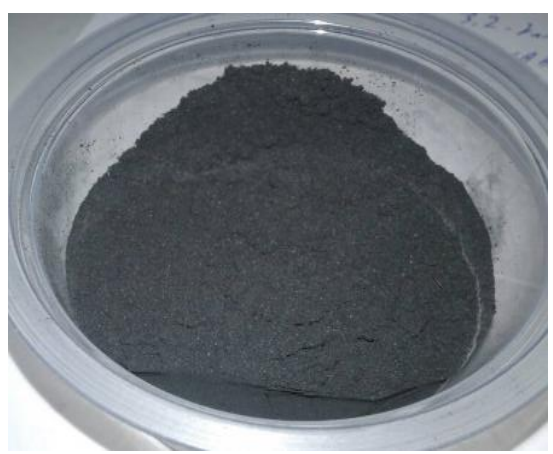

Fig. 2 Palm oil fuel ash (POFA)

\subsection{Fabrication of LFC incorporating BSP and POFA (LFC-BSP-POFA)}

To prepare the lightweight foam concrete, LFC, incorporating banana skin powder, BSP and palm oil fuel ash, POFA, the material were batched and weight. The fabrication of LFC was conducted by mixing cement, sand and water in the concrete mixture with ratios of material as shown in Table 1 . Cement and sand in this table was partially replaced by BSP and POFA, respectively, with various percentages. The cement and 
sand used was Ordinary Portland cement, and sand of particle size less than $0.5 \mathrm{~mm}$ and greater than $0.09 \mathrm{~mm}$, respectively. The banana skin powder was produced first from dried banana skins. The banana skins were dried in an oven at temperature $105^{\circ} \mathrm{C} \pm 5^{\circ} \mathrm{C}$ for 24 hours. Then, the dried banana skin were grinded in a grinder (LA abrasion machine). The grinding process took around two hours. After grinded, the banana skins particles were sieved using $150 \mu \mathrm{m}$ sieve used to remove bigger particles. The dried and sieved BSP were kept under proper container that prevent air moisture from making contact with it.

Table 1: The mix ratio of foamed concrete

\begin{tabular}{|c|c|c|c|}
\hline Material & $\begin{array}{c}\text { Sand to } \\
\text { Cement }\end{array}$ & $\begin{array}{c}\text { Water to } \\
\text { Cement }\end{array}$ & $\begin{array}{c}\text { Foam to } \\
\text { Cement }\end{array}$ \\
\hline Ratio & $2: 1$ & 0.55 & 0.7 \\
\hline
\end{tabular}

For this research, POFA was obtained from Ban Dung Palm Oil Industries Sdn. Bhd. at Parit Sulong, Batu Pahat, Johor. The chemical composition of POFA is as shown in Table 2 [17]. Based on the chemical composition, POFA is classified as Class F Fly Ash in

\begin{tabular}{|c|c|}
\hline Chemical Composition & POFA (\%) \\
\hline Silicon dioxide, $\mathrm{SiO} 2$ & 57.71 \\
\hline Aluminium oxide, $\mathrm{Al} 2 \mathrm{O} 3$ & 4.56 \\
\hline Ferric oxide, $\mathrm{Fe} 2 \mathrm{O} 3$ & 3.30 \\
\hline Calcium oxide, $\mathrm{CaO}$ & 6.55 \\
\hline Magnesium oxide, $\mathrm{MgO}$ & 4.23 \\
\hline Sulphur oxide, $\mathrm{SO} 3$ & 0.25 \\
\hline Sodium oxide, $\mathrm{Na} 2 \mathrm{O}$ & 0.50 \\
\hline Potassium oxide, $\mathrm{K} 2 \mathrm{O}$ & 8.27 \\
\hline Titanium oxide, $\mathrm{TiO} 2$ & - \\
\hline Phosphorus oxide, $\mathrm{P} 2 \mathrm{O} 2$ & - \\
\hline Loss of ignition, $\mathrm{LOI}$ & 10.52 \\
\hline
\end{tabular}

accordance with ASTM C618:2005 [18].

Table 2: Chemical composition POFA [17]

Foam was produced by adding a liquid of synthetic foam agent (Sika AER) to water in the ratio of one portion of liquid agent to 20 portion of water. The foam was added to the mortar mixture (mixture of sand and cement) gradually stage by stage until the targeted density, $1800 \mathrm{~kg} / \mathrm{m}^{3}$, was achieved.

\subsection{Experimental work}

The experimental work include several tests to determine the physical and chemical properties of BSP and POFA, and mechanical properties of LFC-BSP-POFA. The tests for obtaining the physical and chemical properties of BSP and POFA are X-ray Fluorescence (XRF) test and particle size analysis (PSA) test. To determine the mechanical properties of LFC-BSP-POFA, compressive strength test, tensile strength test, modulus of elasticity test, and flexural test were conducted.
XRF test were conducted on BSP and POFA according to ASTM C618-17a [19]. The material were sieved between $50 \mu \mathrm{m}$ to $75 \mu \mathrm{m}(63 \mu \mathrm{m})$ sieve which is to remove larger particles to avoid the failure of XRF. Hydraulic machine was used to compress the sample to become the pallet coin shaped as shown in Fig. 3. The pallet sample is then analyzed under XRF machine.

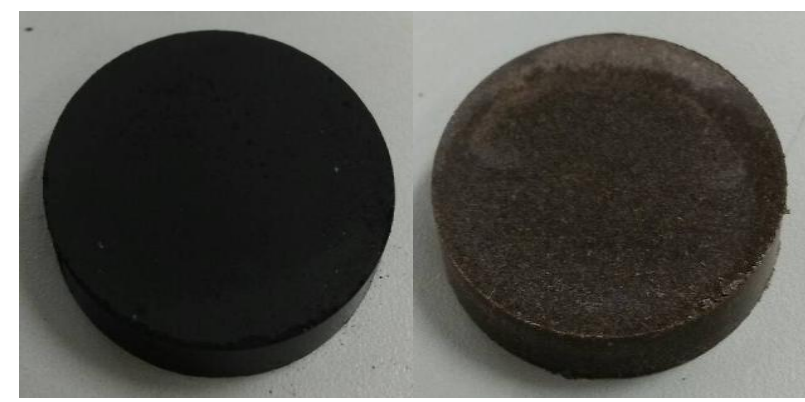

Fig. 3 Pallet sample of POFA (left) and BSP (right)

Meanwhile, PSA test is a test conducted to determine the distribution of particle size of the sample. For this research, the sample taken was in the form of powder

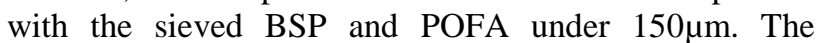
procedure includes placing a small amount of sample gradually into the machine until its concentration achieved near to 80 unit. The machine used ultrasound wave to read the diameter of the sample. The same procedure goes to POFA. Fig. 4 shows the apparatus for PSA tests.

Compressive strength test is a test which determine the strength of the foam concrete according to BS EN 12390-3:2009[20]. The test was conducted on cube samples $(100 \mathrm{~mm} \times 100 \mathrm{~mm} \times 100 \mathrm{~mm})$ of LFC-BSPPOFA at 7 and 28 days. The cube samples were placed in the center of the plate of the testing machine and the load was applied on the cross section are of the cube samples. Tensile strength test is when a cylinder sample is subjected to an axial load under universal testing machine with a specific loading until failure occurred according to BS EN 12390-6:2000 [21]. The cylinder's dimension used is $200 \mathrm{~mm}$ in height and $100 \mathrm{~mm}$ in diameter and tested at 28 days of age. MOE test was conducted in this research according to ASTM C469 Part 2[22]. The determination of modulus of elasticity can be achieved by plotting the stress versus strain graph obtained from the compression test on the cylinder at 28 days. For this test, dial gauge was used to measure the strain. Once the stress strain graph were obtained, the formula were used to calculate the MOE value. Flexural strength test is a four (4) points bending load test which conducted on prism with the size of $500 \mathrm{~mm} \times 100 \mathrm{~mm} \times$ $100 \mathrm{~mm}$ in length, width and thickness at age 28 days according to BS EN12390-5:2009 [23]. 


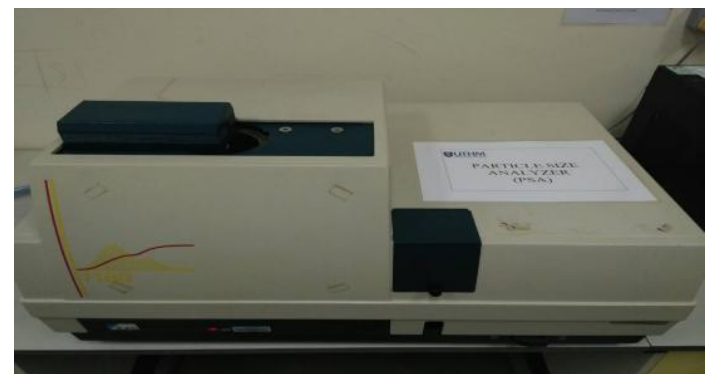

Fig. 4 Apparatus for PSA test

\section{Results and analysis}

The results recorded from the test include chemical and physical properties for cement, BSP and POFA, and mechanical properties LFC-BSP-POFA. The chemical and physical properties for the materials include their chemical compositions and particle distributions. The mechanical properties of LFC-BSP-POFA obtained include compressive strength, tensile strength, modulus of elasticity and flexural behavior.

\subsection{Chemical properties of cement, BSP and POFA}

The chemical composition of cement, BSP and POFA were obtained from the XRF test, as shown in Table 3. From the XRF test conducted on BSP and POFA, its chemical composition were determined. From Table 3, it is seen that cement contain high calcium oxide, $\mathrm{CaO}$, which is $57.7 \%$ and silicon dioxide, $\mathrm{SiO}_{2}$, which is $14.4 \%$. It also contain small percentages of carbon, aluminium oxide, sulphur trioxide, ferric oxide, magnesium oxide and potassium oxide. It is also seen that BSP and POFA contain high silicon dioxide, which are $55.98 \%$ and $51.83 \%$ in BSP and POFA, respectively. Both materials contain small amount of aluminium oxide which are $2.71 \%$ and $2.32 \%$, for BSP and POFA, respectively. Therefore, both materials could be considered as pozzolanic. A pozzolan is defined as siliceous and aluminous materials which contain little cementitious value, which in finely divided form, will chemically react with calcium hydroxide at ordinary temperature to form compound possessing cementitious properties [24].

Table 3. Chemical composition of OPC, BSP and POFA

\begin{tabular}{c|ccc}
\hline Chemical Composition & $\begin{array}{c}\text { OPC } \\
(\%)\end{array}$ & $\begin{array}{c}B S P \\
(\%)\end{array}$ & $\begin{array}{c}P O F A \\
(\%)\end{array}$ \\
\hline Calcium Oxide, $\mathrm{CaO}$ & 57.70 & 8.95 & 8.10 \\
Silicon Dioxide, $\mathrm{SiO} 2$ & 14.40 & 55.98 & 51.83 \\
Carbon, C & 0.10 & - & 0.17 \\
Aluminium Oxide, $\mathrm{Al} 2 \mathrm{O} 3$ & 3.85 & 2.71 & 2.32 \\
Sulphur Trioxide, SO3 & 3.79 & 0.10 & 2.23 \\
Ferric Oxide, Fe2O3 & 2.06 & 1.36 & 7.60 \\
Magnesium Oxide, $\mathrm{MgO}$ & 1.96 & 1.08 & 3.13 \\
Potassium Oxide, K2O & 0.32 & 28.75 & 13.72 \\
Phosphorus Pentoxide, & - & - & 4.30 \\
P2O5 & & & \\
\hline
\end{tabular}

\subsubsection{Pozzolanic Reaction}

When cement, which is rich in calcium oxide, reacts with water molecules, it forms calcium hydroxide as represented by Equation (1).

$$
\mathrm{CaO}+\mathrm{H}_{2} \mathrm{O} \longrightarrow \mathrm{Ca}(\mathrm{OH})_{2} \quad \text { Equation (1) }
$$

When $\mathrm{Ca}(\mathrm{OH})_{2}$ reacts with silicon dioxide $\left(\mathrm{SiO}_{2}\right)$, calcium silicate hydrate, $3(\mathrm{CaO})_{2}\left(\mathrm{SiO}_{2}\right) 3\left(\mathrm{H}_{2} \mathrm{O}\right)$, or known as $\mathrm{C}-\mathrm{S}-\mathrm{H}$ gel is produced. The chemical reaction that took place is called pozzolanic reaction and represented by Equation (2).

$$
3\left[\mathrm{Ca}(\mathrm{OH})_{2}\right]+2\left[\mathrm{SiO}_{2}\right] \longrightarrow\left[3(\mathrm{CaO}) 2\left(\mathrm{SiO}_{2}\right) 3\left(\mathrm{H}_{2} \mathrm{O}\right)\right]
$$

Equation (2)

\subsubsection{Effects of particle size on pozzolanic reaction}

From PSA test conducted, the distribution of particle size of sample is determined. Fig. 5 shows the graph of particle size analysis for cement, BSP and POFA. It is noticed that the finer particles tends to react more effectively with the cement. This is due to pozzolanic reaction which perform better with finer particles [25].

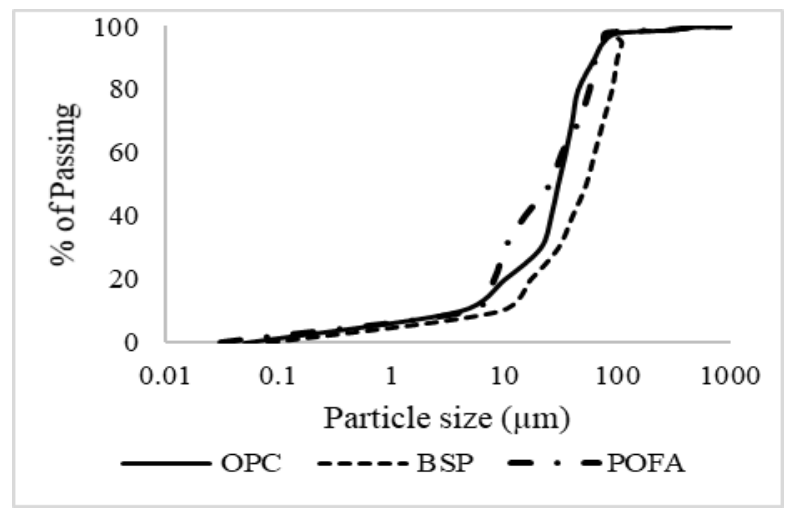

Fig. 5 Particle size analysis for BSP, POFA and cement

BSP particles lay within the range of $0.1 \mu \mathrm{m}$ to $250 \mu \mathrm{m}$. The particles for BSP are increasing from $0.1 \mu \mathrm{m}$ to $12 \mu \mathrm{m}$ slowly with the percentage of passing below $20 \%$. However, above $20 \%$ of passing, the BSP particles are distributed thoroughly as it achieved $100 \%$ of particles passing below $250 \mu \mathrm{m}$. Meanwhile, for POFA, the particles lays within the bigger range of $0.1 \mu \mathrm{m}$ to 100 $\mu \mathrm{m}$. POFA gave the finer particles distribution as compared to BSP. For cement, the better production process from the industry gave fine particles which is above $20 \%$ of passing, the cement particles are distributed thoroughly as it achieved $100 \%$ of particles passing below $50 \mu \mathrm{m}$. The finer particles tends to react more effective as compared to the coarser one. This explained some of the sample from compressive strength of the cubes are getting fluctuated graph, as in Fig. 6 and Fig. 7, as the particles of BSP are coarser in certain 
mixtures compared to others. Coarser material tends to react slower compared to the finer materials.

\subsection{Mechanical properties of LFC-BSP- POFA}

The mechanical properties of LFC-BSP-POFA determined are compressive strength, tensile strength, elastic modulus and flexural strength. The values obtained for each property are compared with the property of control samples which were cast from plain LFC. From this comparison, analysis on significant effects of BSP and POFA on mechanical properties of LFC-BSP-POFA were conducted.

\subsubsection{Compressive strength}

Fig. 6 and Fig. 7 present the compressive strength of LFC-BSP-POFA for $0 \%$ and $15 \%$ POFA as sand replacement, respectively. BSP content for mixture with POFA content of $0 \%$ and $15 \%$ ranged from $0 \%$ to $1 \%$. It is found that compressive strength of LFC-BSP-FOFA is highest with 15\% POFA as sand replacement and 1\% BSP as cement replacement. From Figure 6, the compressive strength of LFC-BSP-POFA with the $0 \%$ of POFA as sand replacement at 7 days, the compressive strength was recorded lowest for $0.2 \%$ content of BSP as cement replacement, which is $18.9 \mathrm{MPa}$. Meanwhile, the highest compressive strength recorded is $27.6 \mathrm{MPa}$ with $0.6 \%$ BSP as cement replacement. The different between the highest and the lowest in compressive strength is 8.7 $\mathrm{MPa}$ which is about $46.0 \%$ increasing in strength. On 28 days, the compressive strength recorded the lowest for $0.2 \%$ of BSP as cement replacement, which is $22.3 \mathrm{MPa}$. The highest compressive strength recorded is $31.7 \mathrm{MPa}$ with $0.8 \%$ BSP as cement replacement. The different between the highest and the lowest in compressive strength is $9.4 \mathrm{MPa}$ which is about $42.2 \%$.

In general, the graphs in Figure 6 and Figure 7 are noticed to fluctuate as opposed to linearly increasing with increase percentage of BSP and POFA. This is due to lack of uniformity of the BSP and POFA's particle size incorporated in the LFC mixture. The fineness of pozzolanic materials have a significant influence on the strength of concrete. Due to relationship between contact surface area and fineness, the finer the BSP and POFA used for cement and sand replacement, the greater the strength obtained compared to the coarser materials. The finer the materials, the higher the amount of total surface area of particles, thus the higher the strength gained by the concrete. The pozzolanic activity increase as the total surface area increased [26].

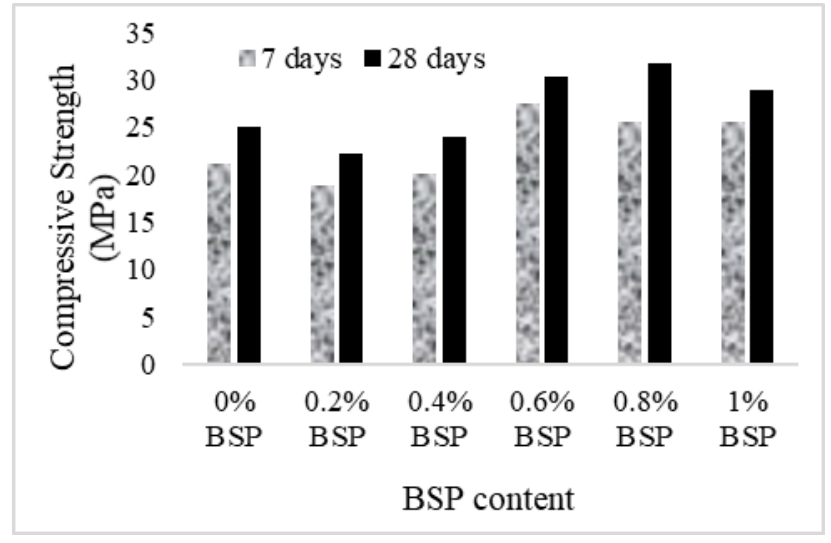

Fig.6 Compressive strength versus BSP content for 0\% POFA

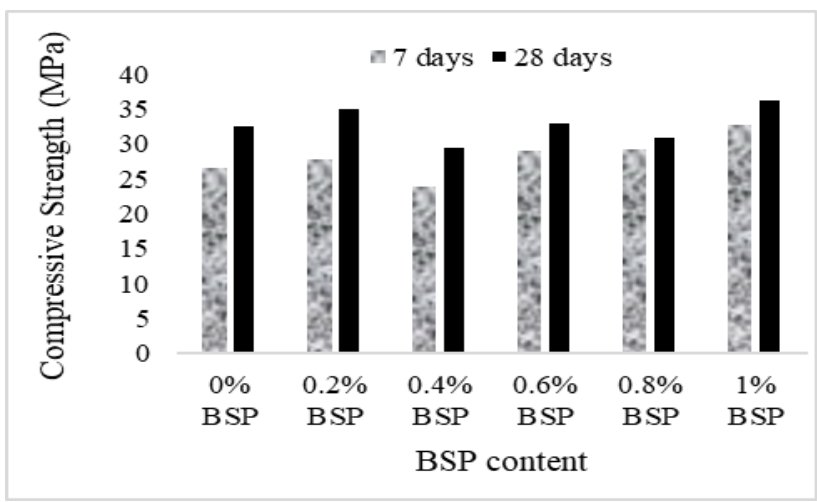

Fig.7 Compressive strength versus BSP content for $15 \%$ POFA

From the compressive strength of LFC-BSP-POFA with the $15 \%$ of POFA as sand replacement at 7 days, the compressive strength recorded lowest value for $0.4 \%$ content of BSP as cement replacement, which is 23.9 $\mathrm{MPa}$. The highest compressive strength recorded is 32.7 $\mathrm{MPa}$ for $1 \% \mathrm{BSP}$ cement replacement. The different between the highest and the lowest in compressive strength is $8.8 \mathrm{MPa}$ which is about $36.8 \%$ increasing in strength. Meanwhile, at 28 days, the compressive strength recorded the lowest value for $0.4 \%$ of BSP as cement replacement, which is $29.7 \mathrm{MPa}$. The highest compressive strength recorded is $36.4 \mathrm{MPa}$ for mixture with $1 \%$ BSP as cement replacement. The different between the highest and the lowest in compressive strength is $6.7 \mathrm{MPa}$ which is about $22.6 \%$ increasing in strength.

From Fig. 6 and Fig. 7, it is concluded that compressive strength of LFC-BSP-FOFA is highest with $15 \%$ POFA as sand replacement and $1 \%$ BSP as cement replacement. It is evidenced that the higher amount of pozzolans added, the higher the strength attained by the foam concrete until it reached its optimum strength. Higher occurance of pozzolanic reaction results in higher strength of mechanical properties of the LFC. 


\subsubsection{Tensile strength}

Fig. 8 shows the results of tensile strength of LFC-BSPPOFA with $0 \%$ and $15 \%$ content of POFA as sand replacement.

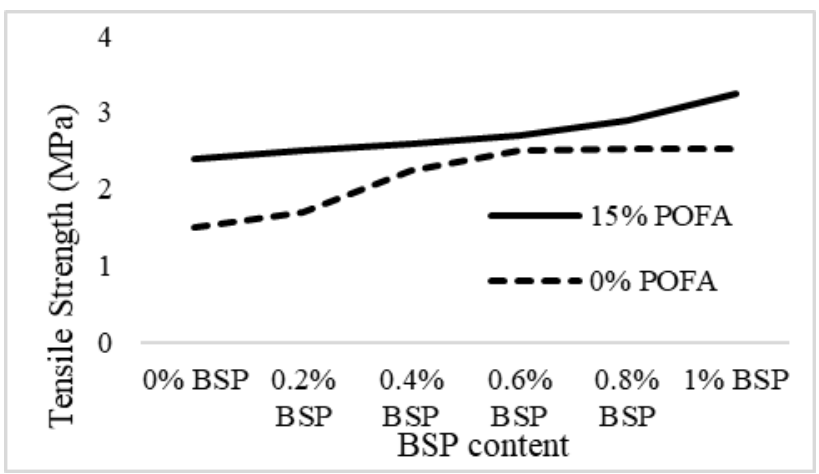

Fig. 8 Tensile strength of LFC-BSP-POFA at 28 days

It is observed from Figure 8, for the mixture with $0 \%$ POFA as sand replacement, the tensile strength increased almost linearly as the percentage of BSP increased until percentage of BSP used was $0.6 \%$ BSP. Adding more percentage of BSP did not increase the tensile strength. Maximum tensile strength recorded was $2.7 \mathrm{MPa}$. The difference between the highest and lowest in tensile strength is $1.15 \mathrm{MPa}$, which also give $74.7 \%$ increasing in tensile strength of LFC-BSP-POFA compared to the control sample at $1.54 \mathrm{MPa}$. The pattern of the curves for $0 \%$ POFA and $15 \%$ POFA is slightly different especially for $0 \%$ to $0.5 \%$ BSP. For LFC with $15 \%$ POFA, the tensile strength is higher even before BSP was added because POFA itself is a pozzolanic material which act as a binder, thus enhanced the bonding of all particles in the LFC mixture.

For the mixtures that include $15 \%$ POFA as sand replacement, the tensile strength achieved was quite constant for every percentage of BSP added. However, when $1 \%$ BSP was added, the tensile strength went up to maxima which was $3.24 \mathrm{MPa}$. The difference of highest and lowest in tensile strength is $1.70 \mathrm{MPa}$, which also give $110.0 \%$ increasing in tensile strength of LFC-BSPPOFA compared to the control sample at $1.54 \mathrm{MPa}$.

From the result, it is found that the maximum tensile strength is achieved in LFC mixture with $1 \%$ BSP and $15 \%$ POFA.

\subsubsection{Modulus of Elasticity}

The determination of modulus of elasticity, MOE, was achieved by using the stress versus strain graph drawn from the data collected from the test. Fig. 9 shows the MOE value of LFC-BSP-POFA at 28 days.

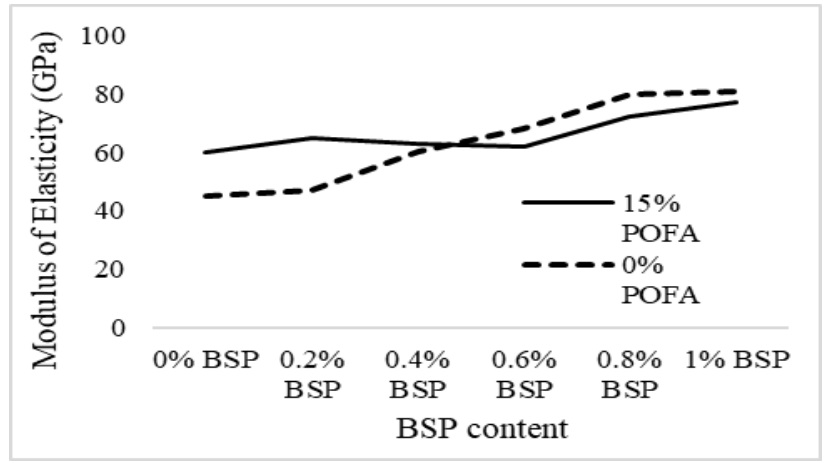

Fig. 9 MOE values of LFC-BSP-POFA at 28 days

From Fig. 9, the MOE values of LFC-BSP-POFA increased almost linearly as the percentage of BSP replacing cement increased for both $0 \%$ and 15\% POFA replacement. The highest value recorded for the MOE is $82000 \mathrm{MPa}$ at 28 days, for $1 \% \mathrm{BSP}$ with $0 \%$ POFA. The highest value of MOE at 28 days is $75000 \mathrm{MPa}$ for $1 \%$ BSP with $15 \%$ POFA. It can be seen that after $0.2 \%$ BSP, the increased POFA replacement level led to reduction in the MOE values. MOE is known to mainly governed by the quality of the interfacial zone [27]. Therefore, it is indicated from the results obtained that POFA has limited effect of POFA on the interfacial zone.

It is evidenced that higher percentage of POFA added reduced the MOE. This trend is similar when POFA is added to self compacting concrete, SCC, where the MOE for SCC incorporating POFA reduced as the percentage of POFA increased [28].

\subsubsection{Flexural strength}

As shown in Fig. 10, the flexural strength of LFC-BSPPOFA is noticed to increase, with small increment, with the increasing percentage of BSP as cement replacement for both mixtures with $0 \%$ and $15 \%$ of POFA. The highest value recorded is $3.9 \mathrm{MPa}$ at 28 days for $1 \% \mathrm{BSP}$ with $15 \%$ POFA.

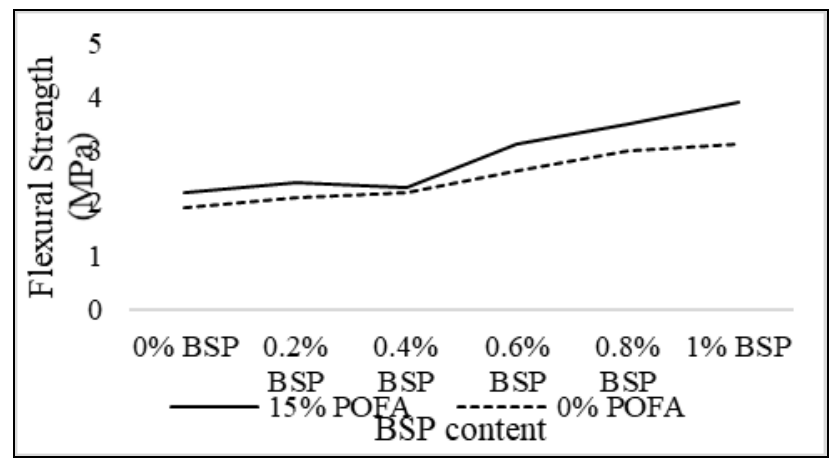

Fig. 10 Flexural strength of LFC-BSP-POFA at 28 days

\subsection{Conclusions}

From the XRF test, the chemical composition of BSP and POFA were determined. Both wastes are high in silicon dioxide, which with $55.98 \%$ and $51.83 \%$ for BSP and POFA, respectively. From the PSA test, it is found that 
the particles for BSP are within $0.1 \mu \mathrm{m}$ to $250 \mu \mathrm{m}$. As for POFA, particles are distributed thoroughly within the range of $0.1 \mu \mathrm{m}$ to $100 \mu \mathrm{m}$. The particles for cement are distributed thoroughly from $0.1 \mu \mathrm{m}$ to $50 \mu \mathrm{m}$. This sizes of BSP and POFA particles are considered fine which chemically react with cement in pozzolanic reaction.

The lowest and highest compressive strength of LFC-BSP-POFA recorded at 28 days are $22.3 \mathrm{MPa}$ and $36.4 \mathrm{MPa}$, respectively. When compared to the control sample, the percentage increased in compressive strength of the highest compressive strength for 28 days is $63.2 \%$.

For tensile strength, the lowest and highest values recorded at 28 days are $1.7 \mathrm{MPa}$ and $3.24 \mathrm{MPa}$, respectively. The lowest tensile strength recorded is $1.54 \mathrm{MPa}$ for control sample. The increased in tensile strength is $1.70 \mathrm{MPa}$, which also give $110.0 \%$ increasing in tensile strength of LFC-BSP-POFA.

The highest value recorded for the MOE is 82000 $\mathrm{MPa}$ at 28 days. The control sample recorded $47091 \mathrm{MPa}$ at 28 days, which is the lowest among all mixtures. This value shows that within the range of study, the highest and the lowest difference in MOE value is $34909 \mathrm{MPa}$ differences, which gives $74.1 \%$ increase in MOE of LFCBSP-POFA compared to the control sample.

For flexural strength, the highest value recorded at 28 days is $3.9 \mathrm{MPa}$. The control sample recorded $2.0 \mathrm{MPa}$ at 28 days, which is the lowest among all mixtures.

The increase of BSP and POFA content in the LFC mixture had shown slight increment in its compressive and tensile strength, modulus of elasticity, and flexure strength.

\section{Acknowledgement}

The authors gratefully acknowledge the funds received from the Ministry if Higher Education Malaysia through the Fundamental Research Grant Scheme (FRGS), VOT No. 1573.

\section{References}

[1] British Cement Association. (1994). Foamed Concrete Composition and Properties. 165-168. British Cement Association.

[2] Fathilah, N.N.F.M. \& Tan, C.S. Flexural Strength of Lightweight Foamed Concrete using cement to sand ratio $3: 1$ with Inclusion of Polypropylene Fibre, 270-279.

[3] Jitchaiyaphum, K., Sinsiri, T., \& Chindaprasirt, P. (2011). Cellular lightweight concrete containing pozzolan materials. Procedia Engineering, 14, 1157-1164.

[4] M.A. Othuman Mydin, N. Mohamad, A.A. Abdul Samad, I.Johari, and M.A. Che Munaaim. Durability performance of foamed concrete strengthened with chemical treated $(\mathrm{NaOH})$ coconut fiber. Proceeding of the $3^{\text {rd }}$ International Conference on Applied Science and technology (ICAST 18). AIP Publishing. 2018]

[5] Noridah Mohamad, Muhamad Afif Iman, M A Othuman Mydin, A A A Samad, J A Rosli1 and A. Noorwirdawati. Mechanical properties and flexure behaviour of lightweight foamed concrete incorporating coir fibre. IOP Conf. Series: Earth and Environmental Science, IconCees 2017. IOP Publishing.

[6] Solomon Ikechukwu Anowai1 and Olorunmeye Fredrick Job. Durability properties of banana fibre reinforced ash concrete. International Research Journal of Engineering and Technology (IRJET) . Vol 4 (11), Pp 1169- 1174

[7] Vishal Gadgihalli, Meena Y.R, Sindhu Shankar, Raghavendra Prasad Havanje Dinakar, S. C. Sharma. Analysis of properties of concrete using dried banana peel powder as admixture. International Journal of Research - Granthaalayah, 5(11), 351-354. 2017.

[8] Patomsok Wilaipon, 2009. The Effect of Briquetting Pressure on Banana-Peel Briquette and the Banana Waste in Northern Thailand, 6(1), pp. 167-171.

[9] P. H. F Pereira, C. Y. Watashi, T. Brocks, K.C.C.C Benini, H.J. C. Voorwald, M.O.H. Cioffi. Mechanical and Thermal Characterization of Banana Peel Fibers/HDPE Composites. ECCM15. $15^{\text {th }}$ European Conference on Composite Materials, Venice, Italy. June 2012.

[10] N. Mohamad, M.S. Zulaika, A.A.A. Samad, W.I Goh, J. Hadipramana and A. Wirdawati. Fresh state and mechanical properties of Self compacting concrete incorporating high volume fly ash. Matec Web of Conference.Vol 47(2016). EDP Sciences. 2016.

[11] Noridah Mohamad, Abdul Aziz Abdul Samad, A. Nadjua, W.I. Goh, A. Anas. Fresh state and mechanical properties of self-compacting concrete incorporating POFA. Jurnal Teknologi. Volume 78(5), Pp 437-441. 2016.

[12] Sh, F.U.E.L.A., Erm, A.S.H., Awal, A.S. M.A., \& Abubakar, S.I. (2011). Properties of concrete containing high volume palm oil fuel ash, 23(2), 54-66.

[13] Richard, A., \& Ramli, M. (2015). The Effects of Curing Methods on Early-age Strength of Sustainable Foamed Concrete. Advances in Research, 3(6), 548-557

[14] Noorwirdawati Ali, Mohd Hazeeq Adhahuddinsa Mohd Sobri, Josef Hadipramana, Abdul Aziz Abdul Samad, and Noridah Mohamad. Potential Mixture of POFA and SCBA as Cement Replacement in Concrete: A Review. MATEC Web of Conferences. ISCEE 2017

[15] Noridah Mohamad, A.A.A. Samad, A. Nadjua, W. I. Goh, A. Anas.Fresh state and mechanical properties of self compacting concrete incorporating POFA May 2016. Jurnal Teknologi. 72(1), Pp 1-6. 2015 
[16] British Standard EN197: Part 1: 2000. Cement composition, specifications and conformity criteria for common cement. British Standard. 2000.

[17] Trangchirapat, W., Janturapitakkul, C. and Chindaprasirt, P. (2009) Use of Palm Oil Fuel Ash as a Supplementary Cementicious Material for Producing High-Strength Concrete. Construction and Building Materials, 23; 2641-2646.

[18] ASTM, C 618 (2005) Standard specification for Coal, Fly Ash and Raw Calcined Natural Pozzolan for use as a Mineral Admixture in Concrete.

[19] ASTM C618-17a. Standard specification for coal fly ash and raw or calcined natural pozzolan for use in concrete. ASTM International. 2017. www.astm.org

[20] BS EN 12390-3. Testing hardened concrete: compressive strength of test specimens. British Standard Institution. 2009

[21] BS 12390-3. Testing Hardened Concrete. British Standard Institution, 3(1), 420-457.

[22] ASTM C469-02. Standard Test method for Static Modulus of Elasticity and Poisson's Ratio of Concrete in Compression. ASTM. 04, 1-5.

[23] BS EN 12390-5. Flexural strength of test specimens. British Institution. 2009

[24] V. H. Dodson. Pozzolans and the pozzolanic reaction. Concrete Admixtures. Pp 159-201. Springer. 1990.

[25] Wunchock Kroehong, Theerawat Sinsiri, Chai Jaturapitakkul. Effect of Palm Oil Fuel Ash Fineness on Packing Effect and Pozzolanic Reaction of Blended Cement Paste. Procedia Engineering, Vol 14(2011), Pp 361-369. 2011.

[26] Lim, O. Y. (2012). Engineering Properties of Lightweight Foamed Concrete Incorporated with Palm Oil Fuel Ash (POFA). Universiti Tunku Abdul Rahman.2012

[27] Alengaram, U.J., Mahmud, H., Jumaat, M.Z. Enhancement and prediction of modulus of elasticity of palm kernel shell concrete. Material Design. Vol. 32(4), Pp. 2143-2148. 2011.

[28] Noridah Mohamad, Abdul Aziz Abdul Samad, A.Nadjua, W.I. Goh, A. Anas. Fresh state and mechanical properties of self compacting concrete incorporating POFA. Jurnal Teknologi, Volume 78(5), Pp. 437-441. UTM. 2016. 